\title{
Learners' Experiences In Using Online-Based Application During COVID-19 Pandemic In English Department
}

\author{
Nuryansyah Adijaya, Zuriyati, Ninuk Lustyantie, Muhamad Sofian Hadi, Aulia Maharani \\ Universitas Negeri Jakarta \\ Email: Nuryansyahadijaya_9906921038@mhs.unj.ac.id
}

\begin{abstract}
During the COVID-19 pandemic, all activities such as teaching and learning activities at college must be carried out online. This online learning activity utilizes online-based learning applications. Every students certainly have their positive and negative response and opinion about using online learning application. Therefore, this research aims to obtain and describe about learners' experiences in using onlinebased learning application during COVID-19 pandemic in English Department. The method of this research is qualitative descriptive study. Data collection was conducted by questionnaire and 1 questions for polling. The respondents of this research were 40 English department learners. To gain in-depth explanation, the researchers also interviewed 7 learners through WhatsApp application. The results showed that students gave positive and negative responses to the use of online-based learning applications.
\end{abstract}

Keywords: Online learning application, pandemic, learners' experiences

\section{INTRODUCTION}

Since the end of 2019, the world, including Indonesia, has been hit by an outbreak of the COVID-19 which is originated in the city of Wuhan, China. The existence of the COVID-19 had a tremendous impact on all fields, one of which is education. Teachers and students were forced to move to digital learning systems or online learning. According to Howlett in Baticulon et al. (2020), he define online learning as the use of electronic technology and media to deliver, support, and enhance both learning and teaching and involves communication between learners and teachers utilizing online content. Meanwhile, according to Jena (2020), online learning is a learning system by utilizing internet.

In situations like this, an online learning application is needed to connect teachers and students even though they are in long distances. Destianingsih, A., \& Satria, A. (2020) state that there are several tools that have been used during English online learning such as Zoom, Google Classroom, Edmodo, Google Meet, E-mail, WhatsApp. In using these applications, certainly need a several things, such as mobile phones, internet data, signals, and adequate phone memory. 
Even though online learning sounds sophisticated because it uses advanced technology and application, it turns out that there are many problems found during the online learning process such as not having internet access, bad signal connection, limited phone memory, and also constant tasks. Efriana, L. (2021) who conduct the research about problems in online learning, the result shown that the implementation of online learning during the Covid-19 pandemic as the part of distance learning has various problems. Those problems are experienced by teachers, students, and parents. The problems faced by teachers include weak mastery of IT and limited access to supervision towards students. The problems of students are in the form of inactivity in following learning, limited supporting facilities, and internet network access. The problem of parents is in the form of limited time in accompanying their children during online learning.

Every student certainly has a perception and also positive and negative response toward the experience of using online-based learning applications. By looking at student responses, it can be a suggestion to all parties involved in teaching and learning applications to build a better online learning atmosphere. Michotte in Agung et al. (2020) states that develops perception as a phase of the total process of action which allows us to adjust our activities to the world, we live in. Here, the students' perception can be described as the developed opinion after having a certain experience that needs adjustment.

Many studies investigated about students' perceptions in using online learning application. For example, Fatimannisa et al. (2020) who conduct the research about "Students' Perception on The Use of Ruang Guru Application in Their English Learning". The result showed that the students' perception on the use of Ruangguru application in their English learning is positive. And also the students' explanation on interview about the perception of Ruangguru explained that Ruangguru is good and interesting online learning platform has a best fitures especially for learning English has a good tutors and Ruangguru can increase their English score in the school.

Another research is Ainun et al. (2020) who conduct the research about "The Students' Perception of Voice Chatting through WhatsApp in Speaking Class". The result showed that majority of students had positive perception toward the implementation of voice chatting through WhatsApp, especially in the aspect of interest and stress level.

Based on the description above and different from those previous researches, the researchers are interested to conduct the research that focuses on learners' experiences in using online-based learning application during COVID-19 pandemic in English Department. The objective of this research is to obtain information about learners' experiences in using online-based learning application during COVID-19 in English Department. The results of this research can serve as suggestions for lecturers and institutions to make online learning in English class better and more optimal.

\section{METHOD}

The method of this research was a qualitative method. According to Creswell (2012), he states that 
the qualitative research is can be taken to refer to research that is based on descriptive data that does not make (regular) use of statistical procedures. To collect the data, the researchers use questionnaires. The questionnaire was adapted from similar previous research written by Famularsih, S. (2020). The questionnaire consists of 5 questions using a Four-Likert scale and 1 questions for polling. The respondents of this research were 40 English Department learners of 2017. To gain in-depth explanation, the researchers also interviewed 7 learners through WhatsApp application.

\section{FINDINGS AND DISCUSSION \\ Questionnaire Result}

In table 1, there are 5 questions about online learning. For question number 1 , most respondents chose Disagree (D), which is $50 \%$. These results indicate that most respondents are difficult to understand the material that posted by lecturers through Google Classroom and Whatsapp Group. Through an interview, the student with the initials AN, she said:

AN : "Saya pribadi memiliki gaya belajar auditori. Jadi saya kurang memahami apabila hanya membaca materi yang dikirim dosen ke whatsapp group atau google classroom. Saya lebih paham jika dosen menjelaskan melalui Zoom.”

AN : "I personally have an auditory learning style. So I don't understand if I only read the material sent by the lecturer to the WhatsApp Group or Google Classroom. I understand better when the lecturer explains through Zoom."
For question number 2, most respondents chose Strongly Agree (SA), 92.5\%, which means they agreed that sending assignments through online learning applications was easier than offline learning. The student with the initials RO said:

RO : "Dengan mengirim tugas melalui aplikasi belajar online, dapat menghemat pengeluaran. Saya tidak perlu ngeprint. Cukup mengirim dalam bentuk softfilenya saja."

$\mathrm{RO}$ : "By sending assignments through online learning application, it can save expenses. I don't need to print the assignments. Just send it in the form of softfile."

For question number 3, most respondents chose Disagree (D), which is $40 \%$, which they do not agree if discussion with friends through online learning applications is easier. The student with the initials GZ said:

GZ : "Saya pribadi lebih suka diskusi dengan bertemu secara langsung. Kalau melalui online, terkadang terhambat oleh sinyal atau internet yang buruk. Misalnya pas video call, sering sekali terjadi delay dan putus-putus. Proses diskusi jadi nggak maksimal."

GZ : "I personally prefer to discussion by meeting in person. If online, sometimes it is distracted by bad signal or internet. For example during a video call, there are often delays and intermittent intervals. So, the discussion process is not optimal."

For question number 4 , most respondents chose Strongly Agree (SA) which is 35\%. They agree that 
the use of online learning applications such as video conferences (Zoom and Google Meet) can improve their listening and speaking skills. The student with the initials AM says:

AM : "Menurut saya, penggunaan Zoom / Google Meet bisa meningkatkan speaking dan listening skill. Saya bisa mendengarkan dosen berbicara dan mengetahui pengucapannya. Selain itu, kadang dosen juga memberikan kita kesempatan untuk menjawab pertanyaan atau menyampaikan pendapat. Sehingga dapat meningkatkan speaking skill saya."

AM : "In my opinion, using Zoom / Gogle Meet can improve my speaking and listening skills. I can listen to lecturers when they are talking and know the pronounciation. In addition, sometimes lecturers also give us the opportunity to answer questions or share the opinion. So that it can improve my speaking skills."

For question number 5, most respondents chose Agree (A), which is 55\%. They prefer online learning than offline learning. The student with the initials AR says:

AR : "Di situasi pandemi seperti ini, tentu saya lebih memilih online learning. Meskipun ada beberapa kendala, seperti sinyal yang buruk dan tugas yang lebih banyak dari biasanya, tetapi mengingat penyebaran virus yang begitu cepat, saya juga takut dan lebih memilih kesehatan saya tentunya. Kalau boleh saran, jangan terlalu banyak memberikan kami tugas."

$\mathrm{AR}$ : "In a pandemic situation like this, of course I prefer online learning. Even though there are some obstacles, such as bad signals and more assignments than usual, but remembering the virus that spread rapidly, I am also afraid and prefer my health of course. If I may suggest, dont give us too much assignments."

In table 2, there are 5 options of favorite online learning applications that are often used. The polling shows that the Zoom application is preferred than other applications. Meanwhile the Kahoot application does not have a voter. Students with the initials FR said:

FR : "Untuk belajar online, aplikasi Zoom lebih bagus dan mudah. Yang paling seru sih, kita bisa melihat dosen dan teman-teman. Suasananya jadi hampir sama seperti belajar secara offline."

FR : "For online learning, the Zoom application is better and easier. The most exciting thing is that we can see our lecturers and friends. The atmosphere is almost the same as learning offline."

Meanwhile, the student with the initials MD said:

MD : "Saya pribadi kurang suka dengan aplikasi Kahoot. Agak ribet. Saya lebih suka menggunakan Google Classroom dan Whatsapp Group. Ngirim tugas jauh lebih mudah dan irit data internet."

MD : "I am not so interest with the Kahoot application. It's a bit difficult. I prefer to use Google Classroom and Whatsapp Group. Sending assignments is much easier and saves on internet data." 
Returning to the result from the responses of the participants, it showed that the students gave a positive response to the use of online learning applications. One of the most favorite applications is Zoom. Several students expressed their opinion about Zoom. Through Zoom, they can hear and see the lecturer delivering the material so that the material is easily absorbed. In addition, they can also improve their speaking and listening skills by listening to lecturers' explanations and answering questions or expressing their opinions. The most exciting thing is, they can meet virtually by activating the camera, so the learning atmosphere through Zoom is almost the same as the offline learning atmosphere.

According to Destianingsih, A., \& Satria, A. (2020), to replace the physical meeting with the students, Zoom is one of the effective tools that can be used as virtual face to face meeting. The teachers provide all learning materials that can be accessed by the students in online English learning and create interactive and convenient atmosphere during online class.

In addition, the Google Classroom and Whatsapp group applications get the second most polling after Zoom. According to them, sending assignments with an online application is easier just by sending it in the form of softfiles and of course this saves expenses because they don't have to submit assignments in the form of hardcopy.

Even so, there were also students who gave negative responses to the use of online learning applications. As in question number 3 , most students disagree about discussion with friends using online learning application is easier. One student expressed her opinion that she prefers to have discussions with friends by meeting in person. The reason is that sometimes the discussion is distracted by a bad signal or internet connection, so the discussion does not run optimally. In addition, there are students who also think that there are more assignments when online learning than offline learning.

Table 1 - Students' Questionnaire

\begin{tabular}{|c|c|c|c|c|c|}
\hline No & Questions & SA & A & $\mathbf{N}$ & D \\
\hline 1 & $\begin{array}{l}\text { The learning material that } \\
\text { posted by the lecturer in Google } \\
\text { Classroom and Whatsapp Group is } \\
\text { easier to understand }\end{array}$ & $37,5 \%$ & $7,5 \%$ & $5 \%$ & $50 \%$ \\
\hline 2 & $\begin{array}{l}\text { Submitting the assignments in } \\
\text { online learning is easier than } \\
\text { offline learning }\end{array}$ & $92,5 \%$ & - & - & $7,5 \%$ \\
\hline 3 & $\begin{array}{l}\text { Discussion with friends through } \\
\text { online learning application is } \\
\text { easier }\end{array}$ & $7,5 \%$ & $27,5 \%$ & $25 \%$ & $40 \%$ \\
\hline 4 & $\begin{array}{l}\text { The use of Zoom and Google Meet } \\
\text { can improve my speaking and } \\
\text { listening skills }\end{array}$ & $35 \%$ & $17,5 \%$ & $15 \%$ & $32,5 \%$ \\
\hline 5 & $\begin{array}{l}\text { In this situation of pandemic, I } \\
\text { prefer online learning than offline } \\
\text { learning }\end{array}$ & $15 \%$ & $55 \%$ & $7,5 \%$ & $22,5 \%$ \\
\hline
\end{tabular}

Table 2 - Students' favourite online application

\begin{tabular}{|c|l|r|}
\hline No & \multicolumn{1}{|c|}{ Questions } & SA \\
\hline 1 & Whatsapp Group & $25 \%$ \\
2 & Zoom & $45 \%$ \\
3 & Google Meet & $5 \%$ \\
4 & Google Classroom & $25 \%$ \\
5 & Kahoot & - \\
\hline
\end{tabular}

\section{CONCLUSION}

This research investigates the experiences of English students using online-based learning applications in the COVID-19 pandemic situation. The analysis of the results from the study showed that students gave positive and negative responses to the use of online-based learning applications. Student opinion is more dominant in using the 
Zoom application which makes the online learning process easier.

According to learners' experiences in this research, learners must try to adapt to new learning methods and applications, remembering that the COVID-19 pandemic is not yet known when it will end, so it is not known when offline learning will begin to be reactivated. In addition, lecturers and the campus also need to pay attention to the conditions and situations of students, considering that not all students have adequate facilities for online learning.

\section{REFERENCES}

Agung, A. S. N., Surtikanti, M. W., \& Quinones, C. A. (2020). Students' Perception of Online Learning during COVID-19 Pandemic: A Case Study on the English Students of STKIP Pamane Talino. SOSHUM: Jurnal Sosial Dan Humaniora, 10(2), 225-235.

Ainun, N. H., Nurweni, A., \& Sholihah, L. (2020, October). The Students' Perception of Voice Chatting through WhatsApp in Speaking Class. In International Conference on Progressive Education (ICOPE).
Baticulon, R. E., Alberto, N. R. I., Baron, M. B. C., Mabulay, R. E. C., Rizada, L. G. T., Sy, J. J., ... \& Reyes, J. C. B. (2020). Barriers to online learning in the time of COVID-19: A national survey of medical students in the Philippines. medRxiv.

Creswell, J. W. (2012). Educational research: planning, conducting, and evaluating quantitative and qualitative research. Boston: Pearson Education, Inc.

Destianingsih, A., \& Satria, A. (2020). Investigating Students' Needs for Effective English Online Learning During Covid-19 for Polbeng Students. ELT-Lectura, 7(2), 147153.

Efriana, L. (2021). Problems of Online Learning during Covid-19 Pandemic in EFL Classroom and the Solution. JELITA, 38-47.

Famularsih, S. (2020). Students' experiences in using online learning applications due to COVID-19 in English classroom. Studies in Learning and Teaching, 1(2), 112-121.

Fatimannisa, A., Dollah, S., \& Abduh, A. (2020). STUDENTS'PERCEPTION ON THE USE OF RUANGGURU APPLICATION IN THEIR ENGLISH LEARNING. Interference: Journal of Language, Literature, and Linguistics, 1(2), 134-140.

Jena, K., P. (2020). Online Learning During Lockdown Period for COVID-19 in India. International Journal of Multidisciplinary Educational Research, VOL 9, ISSUE 5(8). 